\title{
The effect of different physical forms of rapeseed as a fat supplement on the activity of some enzymes in the duodenal chyme of dairy cows
}

\author{
A. Moharrery ${ }^{1,3}$, M. Brask $^{2}$ and M.R. Weisbjerg ${ }^{2}$ \\ ${ }^{1}$ Shahrekord University, Animal Science Department, Agricultural College, P.O. Box 115, Shahrekord, Iran \\ ${ }^{2}$ Aarhus University, Department of Animal Science, Foulum, DK-8830 Tjele, Denmark
}

KEY WORDS: rapeseed, duodenal enzymes, soluble protein, dairy cows

Received: 20 March 2014

Revised: 24 October 2014

Accepted: 28 November 2014

${ }^{3}$ Corresponding author:

e-mail: moharrery@agr.sku.ac.ir

\begin{abstract}
Studies on nutritional regulation of digestive enzymes in ruminants are scarce. Fat supplementation of diets for dairy cows changes the supply of nutrients for absorption and transport. The aim of this experiment was to study the effect of the physical form of rapeseed (Brassica napus) fat on the duodenal enzyme profile in dairy cows. Four mid-lactation Danish Holstein dairy cows were submitted to an experiment with a $4 \times 4$ Latin square design and fed four rations containing $50 \%$ forage and $50 \%$ concentrate on a dry matter basis. The four rations were: a control ration with rapeseed meal (low fat) and three fat-supplemented rations with either rapeseed cake (RSC), whole cracked rape seed (WCR), or rapeseed oil (RSO). The correlation coefficients among duodenal enzyme activities and the relationship between a-amylase and protease activities were examined. Diurnal samples were taken from the duodenum, frozen immediately and stored frozen $\left(-20^{\circ} \mathrm{C}\right)$ before analyses. Additional fat increased the soluble protein content in duodenal chyme $(P<0.05)$. Neither a-amylase nor the protease or soluble sugar concentrations were affected by the treatments. Lipase activity increased for RSO compared with the control. The relationship between $a$-amylase and protease activities showed a parabolic behaviour $(r=0.77 ; P=0.061)$. In conclusion, inclusion of rapeseed oil in the ration of dairy cows under the experimental conditions increased the soluble protein concentration and lipase activity in duodenal chyme.
\end{abstract}

\section{Introduction}

The general feeding practice for high-producing dairy cows promotes the consumption of high-energy diets, which result in large amounts of starch, protein and fat entering the small intestine. Extensive lipolysis of dietary fats takes place in the duodenum and during their absorption from the small intestine (McDonald et al., 2011). Moharrery et al. (2014) concluded from their reviews of the literature (meta-analysis) that starch digestion in the rumen of cows ranged from $22.4 \%$ to $94.2 \%$ of starch intake, indicating very variable starch passage to the small intestine. The pancreatic exocrine secretion contains $\alpha$-amylase, protease and lipase, which play a central role in the digestion of the microbial biomass and other rumen escape nutrients. Small intestinal protein flow stimulates pancreatic $\alpha$-amylase production (Richards et al., 2003). The lipids available for absorption in the small intestine 
are similar to those leaving the rumen (Moore and Christie, 1984), and consist of approximately $80 \%$ to $90 \%$ free fatty acids attached to feed particles (Doreau and Chilliard, 1997). The esterified fatty acids are hydrolysed by intestinal and pancreatic lipases (Doreau and Ferlay, 1994). These enzymes do not completely hydrolyse triacylglycerols, stopping at the monoacylglycerol stage.

Additionally, there is still insufficient quantitative knowledge on enzymatic digestion and absorbed flows of nutrients in the small intestine.

The objectives of the present study were: 1 . to study the effect of different physical forms of rapeseed as fat supplementation on the duodenal enzyme profile in dairy cows, 2 . to examine whether amylase activity is accompanied by a protease activity in the intestinal digesta, and 3 . to determine the correlations among duodenal enzyme activities.

\section{Material and methods}

\section{Cow management, experimental design and sampling}

The experiment was conducted as a $4 \times 4$ Latin square. Four rumen-, duodenum- (open T-piece placed $60 \mathrm{~cm}$ caudal to pylorus) and ileum-fistulated Danish Holstein dairy cows were assigned to one of 4 rations over 4 periods according to a balanced Latin square design; each period lasted 4 weeks. The diets (Table 1) were a low-fat control (rapeseed meal with $4 \%$ fat) (CON) and three fat-supplemented diets: rapeseed cake (RSC) with 17\% fat, whole crushed rape seed (WCR) and rapeseed oil (RSO). All rations were fed as total mixed rations (TMR) that were prepared once a day and fed to the cows ad libitum twice daily at 05.00 and $17.00 \mathrm{~h}$. For further details see Brask et al. (2013).

Diurnal samples were taken from the duodenum to cover every second hour of the day. The samples were pooled, frozen immediately and stored frozen $\left(-20^{\circ} \mathrm{C}\right)$ for 12 months before analyses. After thawing and squeezing through one layer of $45 \mu \mathrm{m} \mathrm{Da}-$ cron mesh, soluble protein and enzyme activity were determined from $30 \mathrm{ml}$ duodenal subsamples. The filtrate was centrifuged at $15000 \mathrm{~g}$ for $15 \mathrm{~min}$ at $4^{\circ} \mathrm{C}$ to precipitate particulate matter, and the supernatant was collected and analysed within $30 \mathrm{~min}$ for determination of soluble protein.

\section{Chemical analysis and determination of duodenal enzyme activities}

Soluble protein. The Lowry colorimetric method (Lowry et al., 1951) was used for measurement of soluble protein (SP). Bovine serum albumin (BSA) was used as the standard.
Table 1. Ingredient and chemical composition of the experimental diets on a dry matter basis

\begin{tabular}{|c|c|c|c|c|}
\hline Item & Control & $\begin{array}{l}\text { Rapeseed } \\
\text { cake }\end{array}$ & $\begin{array}{l}\text { Whole } \\
\text { rape seed }\end{array}$ & $\begin{array}{l}\text { Rapeseed } \\
\text { oil }\end{array}$ \\
\hline \multicolumn{5}{|l|}{ Ingredient, \% } \\
\hline $\begin{array}{l}\text { barley (Hordeum } \\
\text { vulgare) }\end{array}$ & 14.3 & 13.7 & 13.7 & 13.8 \\
\hline RSM, $4 \%$ fat & 19.0 & 6.2 & 14.9 & 18.4 \\
\hline RSC, $17 \%$ fat & 0 & 15.6 & 0 & 0 \\
\hline $\begin{array}{l}\text { whole rape seed } \\
\text { (Brassica napus) }\end{array}$ & 0 & 0 & 6.9 & 0 \\
\hline rapeseed oil & 0 & 0 & 0 & 3.3 \\
\hline $\begin{array}{l}\text { beet (Beta vulgaris) } \\
\text { pulp dried }\end{array}$ & 14.3 & 13.7 & 13.7 & 13.8 \\
\hline $\begin{array}{l}\text { maize (Zea mays- } \\
\text { indentata) silage }\end{array}$ & 23.8 & 23.2 & 23.2 & 23.2 \\
\hline $\begin{array}{l}\text { grass (Lolium } \\
\quad \text { perenne) silage }\end{array}$ & 28.6 & 27.5 & 27.5 & 27.5 \\
\hline \multicolumn{5}{|l|}{ Chemical composition } \\
\hline $\begin{array}{l}\text { dry matter, } \% \\
\text { DM basis }\end{array}$ & 47.9 & 50.0 & 49.2 & 49.4 \\
\hline organic matter, \% & 93.4 & 93.7 & 93.9 & 93.9 \\
\hline $\mathrm{NEL}, \mathrm{MJ} \cdot \mathrm{kg}^{-1}$ & 7.6 & 7.8 & 8.0 & 8.1 \\
\hline crude protein, $\%$ & 16.9 & 17.1 & 16.8 & 17.1 \\
\hline NDF, $\%$ & 33.2 & 32.8 & 32.6 & 32.2 \\
\hline NFC, $\%$ & 39.8 & 38.3 & 38.3 & 38.1 \\
\hline crude fat, $\%$ & 3.5 & 5.5 & 6.2 & 6.5 \\
\hline fatty acids, $\%$ & 2.6 & 4.3 & 5.0 & 5.3 \\
\hline
\end{tabular}

RSM - rapeseed meal; RSC - rapeseed cake, NEL - net energy for lactation, NDF - neutral detergent fibre, NFC - non fibre carbohydrate

Proteases. In cattle, proteases secreted by the abomasum and pancreas hydrolyse dietary protein into small peptides. Amino acids are then released from these early digestion products by peptidases in the cells of the small intestine wall.

The assay procedure for determination of protease activity was based on the Blackburn (1968) method. A unit of proteolytic activity was defined as the amount of enzyme that would solubilize the equivalent of $1.0 \mu \mathrm{g}$ tyrosine in $1 \mathrm{~min}$. The tyrosine equivalent in the background was determined, and enzyme activity reported as $\mu \mathrm{g} \cdot \mathrm{ml}^{-1}$ of sample.

Amylase (1,4, $\alpha$-d-glucanohydrolase, EC 3.2.1.1). The activity of $\alpha$-amylase was determined by measuring the rate of release of reducing sugars during incubation of the sample with starch. For this purpose, $0.25 \mathrm{ml}$ sample, $0.25 \mathrm{ml}$ starch solution ( $1 \mathrm{~g}$ starch in $100 \mathrm{ml}$ distilled water) and $0.5 \mathrm{ml}$ phosphate buffer were mixed in a tube and incubated for $15 \mathrm{~min}$ at $39^{\circ} \mathrm{C}$. Then, for colour development, a dinitrocalycylic acid (DNS) solution was used as described by Moharrery and Das (2001). Enzyme activity was expressed as micrograms of reducing sugars (R-sugar) released per minute per gram per millilitre of sample. Reducing sugar in the background was determined, and enzyme activity reported in $\mu \mathrm{g} \cdot \mathrm{ml}^{-1}$ of sample. 
Lipase (EC 3.1.1.3). Lipase activity was determined by titration of the fatty acids produced by hydrolysis according to the method of Cherry and Crandall, which is explained by Oser (1965). Samples were incubated with an olive oil emulsion and fatty acids produced were titrated with $0.05 \mathrm{~N}$ sodium hydroxide. An auto-titrator (Mettler Toledo ${ }^{\circledR}$ ) was used for titration of the lipase-liberated fatty acids. Units of lipase activity per millilitre of enzyme sample were calculated as millilitres of $\mathrm{NaOH}$ used for titration. Free fatty acids in the background of samples were determined (Oser, 1965), and enzyme activity reported as units per millilitre of sample.

\section{Statistical analysis}

This experiment was designed as a Latin square with four treatments in four periods. All measurements of concentrations and activities were performed in at least duplicate; however, data analysis was performed on mean results per sample. These analyses were performed by the use of the GLM procedure of SAS (2009). If a significant $(P<0.05)$ main effect was detected, the main effect means were separated by the Duncan test (SAS, 2009). The Spearman rank correlations among enzyme activities were estimated using the CORR procedure of SAS (2009), and correlation coefficients were tested using the $t$-test.

\section{Results}

\section{Descriptive statistics of duodenal chyme}

The descriptive statistics for some biochemical parameters of duodenal chyme are presented in Table 2 . The total R-sugar content was highly variable in duodenal chyme, and ranged from 193 to $1018 \mu \mathrm{g} \cdot \mathrm{ml}^{-1}$. Minimum and maximum values for $\alpha$-amylase activity indicate a wide variation in enzyme activity among treatments. The tyrosine equivalent ranged from 33 to $121 \mu \mathrm{g} \cdot \mathrm{ml}^{-1}$ in duodenal chyme. For amylase, protease and lipase activities, the ratios of the upper to lower ranges were 45.7, 2.0 and 5.4, but the concentrations of FFA and soluble protein (SP) showed less variation (Table2). The difference between the highest and lowest value for total R-sugar and tyrosine $\mathrm{E}$ were 825 and $88\left(\mu \mathrm{g} \cdot \mathrm{ml}^{-1}\right)$, respectively.

\section{Treatment effects on duodenal chyme}

Soluble protein (SP) differed among treatments $(P<0.05$; Figure 1). The SP concentration for RSO treatment was $23 \%$ and $11 \%$ higher than control and RSC treatments, respectively $(P>0.05)$.
Table 2. The mean and range of some biochemical parameters in duodenum chyme

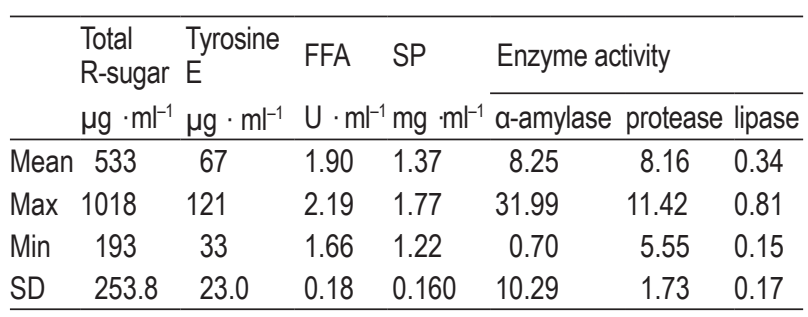

FFA - free fatty acid (see text for unit), SP - soluble protein, Max - maximum, Min - minimum, SD - standard deviation. Units of enzyme activity: $\alpha$-amylase $\left(\mu \mathrm{g} R\right.$-sugar/ml $\left.\cdot \mathrm{min}^{-1}\right)$, protease $\left(\mathrm{U} \cdot \mathrm{ml}^{-1}\right)$, lipase $\left(\mathrm{U} \cdot \mathrm{ml}^{-1}\right)$

The effect of different treatments on soluble protein and enzymatic activity in duodenal chyme are shown in Table 3. R-sugar, tyrosine equivalent, FFA, amylase and protease activities were not affected by treatments. The lipase activity was numerically higher in the three fat-supplemented rations compared with the control, but only the RSO treatment differed significantly from the control $(P<0.05)$.

\section{Correlation between enzyme activities}

All data from the four treatments were pooled to calculate correlation coefficients between enzyme activities and nutrient concentrations (Table 4).

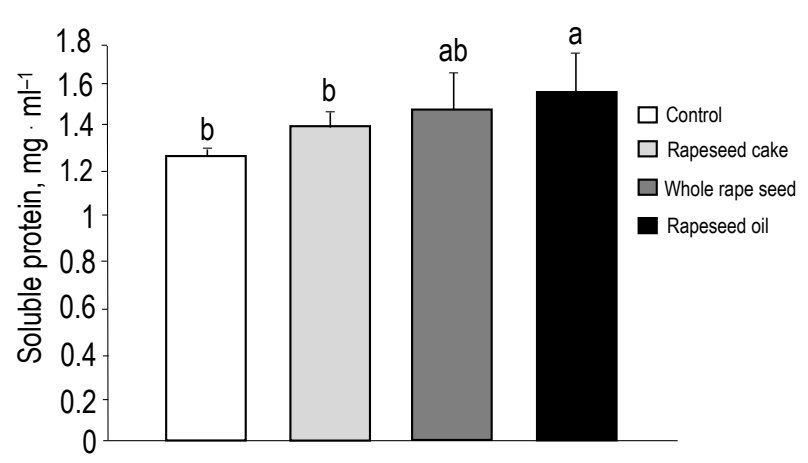

Figure 1. Soluble protein concentration in duodenum chyme

Table 3. Influence of different treatments on enzymatic parameters in duodenum

\begin{tabular}{|c|c|c|c|c|c|c|}
\hline & \multirow{2}{*}{$\begin{array}{l}\text { Total } \\
\text { R-sugar } \\
\mu \mathrm{g} \cdot \mathrm{ml}^{-1}\end{array}$} & \multirow{2}{*}{$\begin{array}{l}\text { Tyrosine } \\
\text { E } \\
\mu \mathrm{g} \cdot \mathrm{ml}^{-1}\end{array}$} & \multirow[t]{2}{*}{ FFA } & \multicolumn{3}{|c|}{ Enzyme activity ${ }^{1}$} \\
\hline & & & & a-amylase & protease & lipase \\
\hline Control & 347 & 61 & 1.94 & 3.39 & 7.84 & $0.181^{b}$ \\
\hline RSC & 602 & 58 & 1.87 & 11.16 & 8.40 & $0.306^{b}$ \\
\hline WCR & 596 & 72 & 1.82 & 10.87 & 8.05 & $0.302^{b}$ \\
\hline RSO & 587 & 77 & 1.96 & 7.61 & 8.37 & $0.582^{a}$ \\
\hline SE & 136.5 & 9.8 & 0.081 & 6.296 & 0.592 & 0.046 \\
\hline$\underline{P}$ & 0.5248 & 0.5395 & 0.6186 & 0.8037 & 0.8893 & 0.0044 \\
\hline
\end{tabular}

${ }^{1}$ units of enzyme activity are: amylase $\left(\mu \mathrm{g}\right.$ R-sugar $\left./ \mathrm{ml} \cdot \mathrm{min}^{-1}\right)$; protease $\left(\mathrm{U} \cdot \mathrm{ml}^{-1}\right)$; FFA and lipase $\left(\mathrm{U} \cdot \mathrm{ml}^{-1}\right)$. Means with the same letter in each column are not significantly different $(P<0.05)$; RSC - rapeseed cake, WCR - whole rape seed, RSO - rapeseed oil, SE - standard error 
Table 4. Correlation coefficients between enzymatic parameters in duodenum chyme

\begin{tabular}{lllrrr}
\hline & Tyrosine E & FFA & \multicolumn{1}{c}{$a$-amylase } & Protease & Lipase \\
\hline R-sugar & $0.371^{1}$ & 0.121 & 0.768 & 0.744 & 0.332 \\
& $0.153^{2}$ & 0.648 & $<0.000$ & 0.005 & 0.202 \\
\multirow{2}{*}{ Tyrosine E } & 0.223 & 0.115 & 0.556 & 0.156 \\
& & 0.384 & 0.664 & 0.025 & 0.556 \\
FFA & & 0.024 & 0.088 & -0.068 \\
& & & 0.926 & 0.738 & 0.797 \\
a-amylase & & & 0.768 & 0.047 \\
& & & & $<0.000$ & 0.856 \\
Protease & & & & 0.018 \\
& & & & & 0.943 \\
\hline
\end{tabular}

${ }^{1}$ coefficient of correlation; ${ }^{2}$ level of probability

The FFA concentration and lipase activity were not correlated with any other enzyme activities or enzyme products. No significant correlation was observed between R-sugar and tyrosine $\mathrm{E}$ concentrations, neither between tyrosine $\mathrm{E}$ and amylase activity. A positive correlation between the tyrosine equivalent concentration and protease activity was found $(P=0.0247)$. The highest positive correlation $(r=0.768)$ was observed between amylase activity and $\mathrm{R}$-sugar concentration and protease activity. R-sugar was also correlated with protease activity $(P=0.005)$.

Among all correlations between enzyme activities, only the correlation between amylase and protease activity was moderate $(r=0.768 ; P=0.0001)$. The relationship between amylase and protease activities was plotted and is presented in Figure 2. Figure 2 shows a parabolic trend between the activities of these two enzymes. The best fit model to describe the relationship between the two enzyme activities is:

Amylase activity $\left(\mu \mathrm{g} \cdot \mathrm{ml}^{-1}\right)=e^{a+\frac{b}{x}+c l n x}$ $\mathrm{a}=379.3 ; \mathrm{b}=-1073.2 ; \mathrm{c}=-116.8 ; r=0.77 ; \mathrm{s}=7.04$ where: $x$ - protease activity as $\mu \mathrm{g} \cdot \mathrm{ml}^{-1}$.

According to the above equation, maximum amylase activity $\left(30.1 \mu \mathrm{g} \cdot \mathrm{ml}^{-1}\right)$ was found for a protease activity of $9.18 \mu \mathrm{g} \cdot \mathrm{ml}^{-1}$.

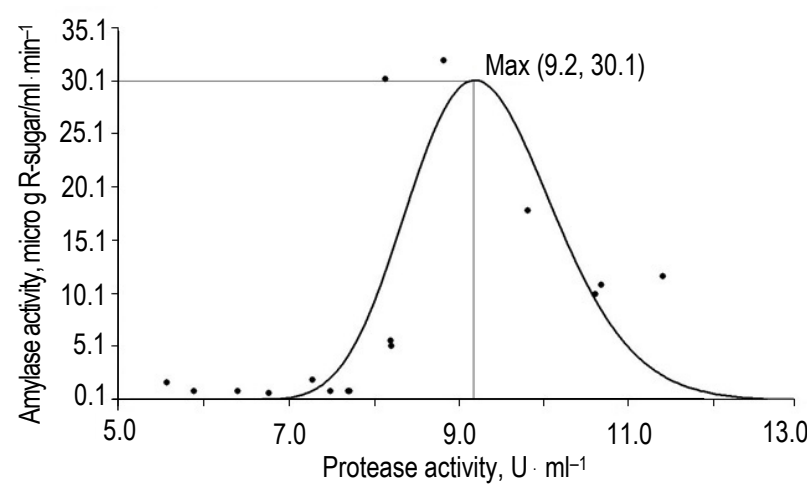

Figure 2. Relationsheep between protease and amylase activites in duodeum chyme

\section{Discussion}

\section{Treatment effects on SP and enzyme activity in duodenal chyme}

Energetically, small intestinal digestion offers efficiency advantages over ruminal fermentation of non-structural nutrients, thus enhancing digestion in the small intestine can be an advantage for highproducing ruminants.

The soluble protein in duodenal chyme of cows on the RSO ration was higher than in the other treatments. Part of this protein originated from the feed protein that escaped from the rumen. There has been a widely held and long standing assumption that the soluble nitrogen fraction of dietary protein is rapidly and extensively degraded in the rumen (Ørskov and McDonald, 1979). However, Stefański et al. (2013) predicted that the effective protein degradability in the rumen of soluble rapeseed meal protein as $43 \%$, close to earlier estimates of $44 \%$ (Hedqvist and Udén, 2006). Further, several reports have indicated that a part of the protein fractions corresponding to A and B1 in the Cornell Net Carbohydrate and Protein System can escape the rumen (Volden et al., 2002; Reynal et al., 2007). Current measurements indicate that the RSO treatment increased the soluble protein concentration in duodenal chyme. In agreement, Jenkins (1993) reported that fat supplements can interfere with fermentation and reduce microbial protein synthesis in the rumen. In sheep (Ovis aries), rumen infusion of linseed oil decreased protein digestion in the rumen and was accompanied by a decreased rumen ammonia concentration and increased dietary nitrogen flow to the duodenum (Ikwuegbu and Sutton, 1982).

Sugar content showed high correlation to amylase activity in the duodenal chyme, but it seems that other parameters that can affect solubility of starch or interaction between other nutrients may interfere with amylase activity. Based on the measured activity of this enzyme and the measured duodenal nutrient flow, duodenal amylase theoretically has the potential to hydrolyse all starch. This is in agrement with Owens et al. (1986), who stated that there was no evidence that incomplete starch digestion in the small intestine of ruminants was due to insufficient amylase activity.

Protein hydrolysis is a multi-step process in the small intestine. The tyrosine equivalent, as a product of protein hydrolysis, did not negatively affect protease activity among treatments (Table 4). According to the present study (Table 2), it can be concluded that the capacity of the small intestine for protein hydrolysis was approx. $3.5 \mathrm{~kg}$ per day. Under normal conditions, 
intestinal protease has sufficient potential for hydrolysing protein, but some conditions and interactions between nutrients in the intestine will reduce its activity. The capacity for small intestinal protein hydrolysis is generally assumed to be high (Owens and Bergen, 1983), but most values for small intestinal protein digestibility fall in the range of $65 \%$ to $90 \%$ (NRC, 2001). However, the pancreatic response of ruminants is difficult to predict, and the literature suggests that complex interactions exist between nutrients and hormones in ruminants (Swanson and Harmon, 2002). For example, it was hypothesized that increasing post ruminal protein may be a way to increase $\alpha$-amylase secretion and improve post ruminal starch digestion in beef steers.

Lipase activity differed among treatments (Table 3). Cows on RSO treatment showed the highest lipase activity in the duodenal chyme. Romo et al. (2000) reported that total fat digestibility was increased by abomasal infusion of fat mixtures. This suggests that adequate amounts of abomasal and intestinal lipase activity are present for digestion and absorption of fatty acids from triacylglycerols. Enjalbert et al. (2003) reported that ruminal metabolism of unsaturated fatty acids differed between rapeseed meal and raw rape seeds due to processing. Experiments evaluating pancreatic lipase response to dietary triacylglycerol have given variable results, but generally, pancreatic lipase increases when triacylglycerol is increased in the diet. Data regarding lipase secretion in ruminants are scarce. Both cattle and sheep secrete pancreatic lipase with hydrolytic characteristics that are similar to those of the non-ruminant (Noble, 1978). Brannon (1990) summarized numerous studies for non-ruminants and reported that pancreatic lipase activity increases by $170 \%$ to $800 \%$ in response to increased dietary tri-acylglycerol. One explanation for the variability is the source of supplemented fat. Ricketts and Brannon (1992) reported an interaction between degree of saturation of the fat and quantity of fat in the diet. In contrast, Johnson (1973) examined secretion of pancreatic juice and lipase in sheep infused duodenally with safflower (Carthanus tinctorius) or coconut (Cocos nycifera) oils in quantities equivalent to $5 \%$ or $10 \%$ of their dry matter intake of lucerne (Medicago sativa). Infusion of both lipid sources at the mentioned levels decreased both total pancreatic secretion and secretion of lipase. A number of factors have been suggested in the regulation of pancreatic lipase. Secretin, free fatty acids, and ketones all increase pancreatic lipase concentrations (Brannon, 1990). Fatty acids are effective in increasing pancreatic lipase both when administered in the diet or intravenously (Lahaie, 1984).

\section{Correlation between enzyme activities}

Intestinal starch digestion provides free glucose (Huntington, 1997) and with increasing starch concentration (within the capacity range of amylase activity) glucose production was increased ( $r=0.768$; Table 4). In agreement with our result, Chittenden et al. (1984) reported that duodenal glucose infusion increased pancreatic $\alpha$-amylase secretion.

Protease activity showed a positive correlation with the tyrosine equivalent concentration in duodenal chyme. It seems that the tyrosine equivalent concentration as the end-product of protease action did not suppress protease activity. However, in the present study the tyrosine equivalent concentration in the duodenal chyme was probably not high enough to produce a negative feedback effect on protease activity. On the other hand, it has been reported that the presence of protein in the small intestine released two hormones, one of which increased the production of proteases and lipase, while the other increased amylase release (Magee and Hong, 1959).

According to the 'parallel' secretion of enzymes (Babkin, 1950), a positive correlation between protease and amylase activities was expected, because the pancreas exocrine secretion contains both amylase and protease. However, the relationship was parabolic (Figure 2) between the activities of the two enzymes, where they first increased simultaneously in concentration, then at a certain protease activity, amylase was digested, thereby amylase activity decreased (Babkin, 1950). However, the interrelationship between enzyme activity in duodenal chyme is very complex, because factors other than proteolytic inactivation have also been postulated to account for selective changes in pancreatic enzyme activities during passage through the small intestine. For example, homologous enzyme inhibitors are known to be present in rat (Grossman, 1958), dog (Kalser and Grossman, 1955) and human pancreatic juice (Figarella et al., 1969). Although the action of the secreted inhibitors is usually transient due to degradation of the enzyme-inhibitor complexes and digestion of the inhibitor, the secreted inhibitor is specific for one enzyme and does not inhibit other enzymes. Inhibitory activity could therefore account for changes in the ratio between enzyme activity in intestinal contents (Wormsley and Goldberg, 1972).

\section{Conclusions}

Supplementation of rapeseed oil to the ration of dairy cows increased the soluble protein concentration in duodenal chyme by $23 \%$ and $17 \%$ compared 
with control and rapeseed cake groups, respectively. Adding fat as rapeseed oil increased the lipase activity in the duodenum. In the present experiment the relationship between amylase and protease activity showed a parabolic trend.

\section{Acknowledgements}

We thank Torkild Jakobsen and Hanne Berg for help with the experimental work. The first author would like to express his gratitude to the Faculty of Agricultural Science, University of Aarhus, for hosting his sabbatical.

\section{References}

Babkin B.P., 1950. Secretory Mechanisms of the Digestive Glands. $2{ }^{\text {nd }}$ Edition. Hoeber, New York, pp. 54-58

Blackburn T.H., 1968. Protease production by Bacteroides amylophilus strain H18. J. Gen. Microbiol. 53, 27-36

Brannon P.M., 1990. Adaptation of the exocrine pancreas to diet. Annu. Rev. Nutr. 10, 85-105

Brask M., Lund P., Weisbjerg M.R., Hellwing L.F., Poulsen M., Larsen M.K., Hvelplund T., 2013. Methane production and digestion of different physical forms of rapeseed as fat supplements in dairy cows. J. Dairy Sci. 96, 2356-2365

Chittenden L., Johnson W., Mitchell D.D. Jr. G.E., Tucker R.B., 1984. Ovine pancreatic amylase response to form of carbohydrate. Nutr. Rep. Int. 29, 1051-1060

Doreau M., Chilliard Y., 1997. Digestion and metabolism of dietary fat in farm animals. Brit. J. Nutr. 78, S15-S35

Doreau M., Ferlay A., 1994. Digestion and utilization of fatty-acids by ruminants. Anim. Feed Sci. Tech. 45, 379-396

Enjalbert F., Eynard P., Nicot M.C., Troegeler-Meynadier A., Bayourthe C., Moncoulon R., 2003. In vitro versus in situ ruminal biohydrogenation of unsaturated fatty acids from a raw or extruded mixture of ground canola seed/canola meal. J. Dairy Sci. 86, 351-359

Figarella C., Clemente F., Guy O., 1969. On zymogens of human pancreatic juice. FEBS Lett. 3, 351-353

Grossman M.I., 1958. Some properties of trypsin inhibitor of pancreatic juice. Proc. Soc. Exp. Biol. Med. 99, 304-306

Hedqvist H., Uden P., 2006. Measurement of soluble protein degradation in the rumen. Anim. Feed Sci. Tech. 126, 1-21

Huntington G.B., 1997. Starch utilization by ruminants: From basics to the bunk. J. Anim. Sci. 75, 852-867

Ikwuegbu O.A., Sutton J.D., 1982. The effect of varying the amount of linseed oil supplementation on rumen metabolism in sheep. Brit. J. Nutr. 48, 365-370

Jenkins T.C., 1993. Lipid metabolism in the rumen. J. Dairy Sci. 76 , 3851-3863

Johnson T.O., 1973. Ovine and avian pancreatic lipase response to source and level of dietary fat. MSc. Thesis, University of Kentucky, Lexington, KY (USA)

Kalser M.H., Grossman M.I., 1955. Secretion of trypsin inhibitor in pancreatic juice. Gastroenterology 29, 35-45

Lahaie R.G., 1984. Dietary regulation of protein synthesis in the exocrine pancreas. J. Pediat. Gastroenterol. Nutr. 3, S43-S50

Lowry O.H., Rosebrough J.J., Farr A.L., Randall R.J., 1951. Protein measurement with the Folin phenol reagent. J. Biol. Chem. 193, 265-275
Magee D.F., Hong S.S., 1959. Daily output of pancreatic juice and some dietary factors which influence it. Amer. J. Physiol. 197, 27-30

McDonald P., Edwards R.A., Greenhalgh J.F.D., Morgan C.A., Sinclair L.A., Wilkinson R.G., 2011. Animal Nutrition. $7^{\text {th }}$ Edition. Prentice Hall Publisher

Moharrery A., Das T.K., 2001. Correlation between microbial enzyme activities in the rumen fluid of sheep under different treatments. Reprod. Nutr. Dev. 41, 513-529

Moharrery A. Larsen M., Weisbjerg M.R., 2014. Starch digestion in the rumen, small intestine, and hind gut of dairy cows -A meta-analysis. Anim. Feed Sci. Tech. 192, 1-14

Moore J.H., Christie W.W., 1984. Digestion, absorption and transport of fats in ruminant animals. In: J. Wiseman (Editor). Fats in Animal Nutrition. Butterworths, London (UK), pp. 123-149

Noble R.C., 1978. Digestion, absorption and transport of lipids in ruminant animals. Prog. Lipid Res. 17, 55-91

NRC, 2001. Nutrient Requirements of Dairy Cattle. $7^{\text {th }}$ revised Edition. National Academy Press.Washington, DC

Oser B.L., 1965. Hawk's Physiological Chemistry. 14 $4^{\text {th }}$ Edition. TATA McGraw-hill Publishing Co. LTD. New Delhi, pp. 1123

Owens F.N., Bergen W.G., 1983. Nitrogen metabolism of ruminant animals: Historical perspective, current understanding and future implications. J. Anim. Sci. 57, Suppl. 2, 498 (Abstr.)

Owens F.N., Zinn R.A., Kim Y.K., 1986. Limits to starch digestion in the ruminant small intestine. J. Anim. Sci. 63, 1634-1648

Ørskov E.R., McDonald I., 1979. The estimation of protein degradation in the rumen from incubation measurements weighted according to rate of passage. J. Agr. Sci. 92, 499-503

Reynal S.M., Ipharraguerre I.R, Lineiro M., Brito A.F., Broderick G.A., Clark J.H., 2007. Omasal flow of soluble protein, peptides, and free amino acids in dairy cows fed diets supplemented with proteins of varying ruminal degradabilities. J. Dairy Sci. 90, 1887-1903

Richards C.J., Swanson K.C., Paton S.J., Harmon D.L., Huntington G.B., 2003. Pancreatic exocrine secretion in steers infused postruminally with casein and corn starch. J. Anim. Sci. 81,1051-1056

Ricketts J., Brannon P.M., 1992. Preferential regulation of pancreatic lipase by polyunsaturated dietary fat. Fed. Amer. Soc. Exp. Biol. J. 6, A1841 (Abstr.)

Romo G.A., Erdman R.A., Teter B.B., Sampugna J., Casper D.P., 2000. Milk composition and apparent digestibilities of dietary fatty acids in lactating dairy cows abomasally infused with cis or trans fatty acids. J. Dairy Sci. 83, 2609-2619

SAS, 2009. User's Guide: Statistics, Version 9.2. SAS Institute Inc. Cary, NC

Stefański T., Ahvenjärvi S., Huhtanen P., Shingfield K.J., 2013. Metabolism of soluble rapeseed meal (Brassica rapa L.) protein during incubations with buffered bovine rumen contents in vitro. J. Dairy Sci. 96, 440-450

Swanson K.C., Harmon D.L., 2002. Dietary influences on pancreatic alpha-amylase expression and secretion in ruminants. In: R. Zabielski, P.C. Gregory, B. Weström (Editors). Biology of the Intestine in Growing Animals. Elsevier Science, New York, pp. 515-537

Volden H., Mydland L.T., Olaisen V., 2002. Apparent ruminal degradation and rumen escape of soluble nitrogen fractions in grass and grass silage administered intraruminally to lactating dairy cows. J. Anim. Sci. 80, 2704-2716

Wormsley K.G., Goldberg D.M., 1972. The interrelationships of the pancreatic enzymes. Gut 13, 398-412 